\title{
Erratum to: Determination of selenium in coal fly ash via $\gamma-\gamma$ coincidence neutron activation analysis
}

\author{
M. Yoho $^{1} \cdot$ S. Landsberger ${ }^{1}$
}

Published online: 3 July 2015

(c) Akadémiai Kiadó, Budapest, Hungary 2015

\section{Erratum to: J Radioanal Nucl Chem DOI 10.1007/s10967-015-4209-z}

Unfortunately, the affiliation of authors is incorrect in the original publication. The correct affiliation is given in this erratum.

The online version of the original article can be found under doi:10.1007/s10967-015-4209-z.

S. Landsberger

s.landsberger@mail.utexas.edu

1 Nuclear Engineering Teaching Lab, The University of Texas at Austin, Pickle Research Campus R-9000, Austin, TX 78712, USA 